\title{
FERRAMENTAS DE AVALIAÇÃO PARA AVALIAR A INDEPENDÊNCIA: UMA SCOPING REVIEW
}

\author{
INSTRUMENTS TO ASSESS INDEPENDENCE: A SCOPING REVIEW
}

Herramientas de EValuacíon Para eValuar la independencia: un SCoping ReVIeW

DOI 10.33194/rper.2022.193

Submission date: 2021-09-23 Acceptance date: 2022-01-04 Online publication date: 2022-01-22

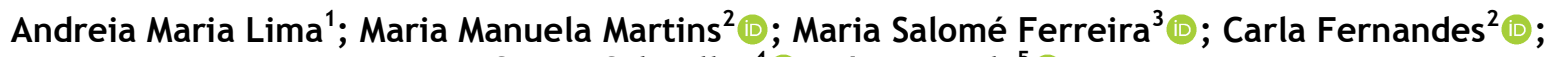
Soraia Schoeller ${ }^{4}$; ; Vítor Parola ${ }^{5}$ (1)

${ }^{1}$ Instituto de Ciências Biomédicas Abel Salazar, Escola Superior de saúde - Fernando Pessoa, Porto, Portugal

${ }^{2}$ Escola Superior de Enfermagem do Porto - CINTESIS, Porto, Portugal

${ }^{3}$ Instituto Politécnico de Viana do Castelo - Escola Superior de Saúde, Viana do Castelo, Portugal

${ }^{4}$ Departamento de Enfermagem, Programa de Pós-Graduação de Enfermagem, Universidade Federal de Santa Catarina, Florianópolis, Brasil
\end{abstract}

${ }^{5}$ Escola Superior de Enfermagem de Coimbra, Coimbra, Portugal; Unidade de Investigação em Ciências da Saúde: Enfermagem (UICISA: E). Portugal Centre for Evidence-Based Practice: A JBI Centre of Excellence

\section{Corresponding author: Andreia Maria Lima, alima2358@hotmail.com}

\section{RESUMO}

Introdução: A independência é uma área privilegiada de intervenção do enfermeiro. A maioria das situações que motivam os internamentos, levam a uma considerável diminuição da independência da pessoa. Existem muitas escalas que mensuram a independência, pelo que é importante conhecê-las e aplicá-las adequadamente.

Metodologia: Scoping review com base nos princípios preconizados pelo Joanna Briggs Institute. Realizou-se uma pesquisa nas bases de dados: Scopus (excluindo MEDLINE), CINAHL complete (via EBSCO, Excluindo MEDLINE) e MEDLINE (via PubMed).

Resultados: Após a análise segundo os critérios de inclusão estabelecidos, foram selecionados 26 artigos, os quais fazem alusão a seis instrumentos diferentes que avaliam a independência, a saber: Functional Independence Measurement, Instrumental Activity of Daily Living Scale, Barthel Index, Katz Index of Independence in Activities of Daily Living, a Assessment of Living Skills and Resources e a Utrecht Scale for Evaluation of Rehabilitation.

Discussão: Os títulos dos instrumentos por vezes não traduzem se mensuram apenas e/ou só a independência. Quando combinada a aplicação dos diferentes instrumentos, poderá no seu conjunto dar resposta ao conceito de independência.

Conclusão: Na prática clínica é importante conhecer todos os instrumentos ao dispor para a sua aplicação, conhecendo também as suas caraterísticas e aplicabilidade. Reconhece-se que os resultados da aplicação destas ferramentas, permite caraterizar as necessidades das pessoas e responder de uma forma atempada a essas necessidades.

DESCRITORES: Vida independente; Assistência ao paciente; Promoção da saúde; Enfermagem em reabilitação; Pesos e medidas

\section{ABSTRACT}

Introduction: Independence is a privileged area of intervention for nurses. Most situations that motivate hospitalizations lead to a considerable decrease in the person's independence. There are many scales that measure independence, so it is important to know them and how to apply them properly.

Methodology: Scoping review based on the principles advocated by the Joanna Briggs Institute. A search was carried out in the following databases: Scopus (excluding MEDLINE), CINAHL complete (via EBSCO, excluding MEDLINE) and MEDLINE (via PubMed).

Results: After the analysis according to the established inclusion criteria, 26 articles were selected, which allude to six different instruments that assess independence, namely Functional Independence Measurement, Instrumental 
Activity of Daily Living Scale, Barthel Index, Katz Index of Independece in Activities of Daily Living, the Assessment of Living Skills and Resources and the Utrecht Scale for Evaluation of Rehabilitation.

Discussion: Instrument titles sometimes do not translate if they only measure and/or only independence. When the application of the different instruments is combined, it enables, as a whole, to respond to the concept of independence.

Conclusion: In clinical practice, it is important to know all the instruments available in order to apply them, also knowing their characteristics and applicability. It is recognized that the results of the application of these tools allow for the characterization of people's needs and permits a response, in a timely manner, to those needs.

DESCRIPTORS: Independent living; Patient care; Health promotion; Rehabilitation nursing; Weights and measures

\section{RESUMEN}

Introducción: La independencia es un ámbito de intervención privilegiado para las enfermeras. La mayoría de situaciones que motivan las hospitalizaciones conllevan una disminución considerable de la independencia de la persona. Hay muchas escalas que miden la independencia, por lo que es importante conocerlas y aplicarlas correctamente.

Metodología: Scoping review basada en los principios defendidos por el Instituto Joanna Briggs. Se realizó una búsqueda en las siguientes bases de datos: Scopus (excluyendo MEDLINE), CINAHL complete (vía EBSCO, excluyendo MEDLINE) y MEDLINE (vía PubMed).

Resultados: Luego de un análisis según los criterios de inclusión establecidos, se seleccionaron 26 artículos, aludiendo a seis instrumentos diferentes que evalúan la independencia, a saber: Functional Independence Measurement, Instrumental Activity of Daily Living Scale, Barthel Index, Katz Index of Independence for Activities of Daily Living, Assessment of Living Skills and Resources y Utrecht Scale for Evaluation of Rehabilitation.

Discusión: Los títulos de los instrumentos a veces no se traducen si solo miden y / o solo la independencia. Cuando se combine la aplicación de los diferentes instrumentos, podrá responder en su conjunto al concepto de independencia.

Conclusión: En la práctica clínica es importante conocer todos los instrumentos disponibles para su aplicación, conociendo también sus características y aplicabilidad. Se reconoce que los resultados de la aplicación de estas herramientas nos permiten caracterizar las necesidades de las personas y responder de manera oportuna a esas necesidades.

DESCRIPTORES: Vida independiente; Atención al paciente; Promoción de la salud; Enfermería em rehabilitación; Pesos y medidas

\section{INTRODUCTION}

Independence is understood as the person's ability to carry out their activities of daily living, without the help of a third party. Therefore, it comprises the functional capacity for carrying out day-to-day tasks . Other authors also define it as self-care, pointing out that this self-care covers special care capacities, including bathing, eating, dressing, using the toilet, positioning, and transferring .

Analysis of the concept of independence and autonomy, concludes that the latter involves the concept of independence, since, as Beauchamp and Childress point out, independence allows the person to practice the right to freedom and authority arising from autonomy . It is essential to know their meanings, and as emphasized by Watson, the nurse, as the holder of knowledge and skills capable of responding to the needs of the person whom they care for, it is their concern to understand everything that involves and surrounds the concepts for its concretization, implementation, and monitoring. This knowledge assumes particular importance, when the goals of the professionals who care, focus especially on the rehabilitation of the person, whether at the physical, cognitive, psychological and/or social level.

Disease processes affect people's health and quality of life, who are their carriers. However, these repercussions may take on even more generous proportions if the person is hospitalized, since this, for several reasons, namely for bureaucratic and organizational aspects of care, promotes immobility processes, which contribute to dependency, especially in the elderly. The recovery of independence in these people, if there is no intervention, can be called into question, since immobility has consequences in all organic systems and in the elderly, due to their vulnerability, these assume greater severity .

People who experience independence, simultaneously refer to greater happiness and satisfaction with life, and consequently, greater quality of life . 
In health-disease processes, the person loses and regains their independence, so it is necessary that health professionals, especially nurses, know the gains or losses in this area through its evaluation, being necessary to know the instruments available and their characteristics. To analyze and select the appropriate instrument, these professionals need to remember or know the limits of each concept they intend to develop, since this is the only way to direct their care and systematize it, aiming to realize their purposes.

Aware of this need and using a scoping review, it is intended to map the evidence to identify and analyze the instruments used to assess the person's independence, which emerges from scientific production.

\title{
METHODOLOGY
}

The search for evidence using systematic review is at the heart of evidence-based practice in most scientific areas, especially in nursing. We opted for a scoping review. It is an investigation methodology that aims to map the existing scientific evidence implicit to an area of research and identify the inadequacies in the existing evidence .

The present study is a scoping review that sought to evaluate the existing evidence and to know the instruments used by health professionals to assess the person's independence. Taking into consideration the knowledge that we wanted to synthesize, the review had as its starting point the following question: "What are the instruments used to assess the person's independence?".

Using the strategy: participants, concept and context (PCC), studies were included in the Scoping review that: a) address health professionals caring for the adult person; b) addressing the person's independence; c) and using instruments to assess independence in all care settings; d) regarding the type of study, quantitative studies were examined. For this purpose, an electronic search was carried out in the Scopus, MEDLINE $®$ (Medical Literature Analysis and Retrieval System Online) databases via PubMed, and CINAHL ${ }$ (Cumulative Index to Nursing and Allied Health Literature) via EBSCO.

The research was developed in three stages. First, a limited search was conducted in the MEDLINE (via PubMed) and CINAHL (via EBSCO) databases to list the most commonly used words in the titles and abstracts of articles developed in the intended scientific area well as the indexing terms.

The second search was performed using the keywords and index terms identified, in the included databases, adapted according to the specificities of each database (Table 1). Finally, the list of references for each selected study was analyzed to include potential additional studies. Studies wrote in English, Spanish, and Portuguese, published between 2010 and 2020, were considered for inclusion in this review.

Table 1 - Research strategy applied by database and the respective search results by database.

\author{
Database: Scopus \\ Filters: Excluding MEDLINE \\ Results: 813 \\ Search strategy (18 de abril de 2020) \\ Database: CINAHL complete (via EBSCO) \\ Filters: Excluding MEDLINE \\ Results: 313 \\ Search strategy (18 de abril de 2020) \\ S1 - MH Patients OR TI patient* OR AB patient* \\ S2 - MH Patient Autonomy OR TI independence OR AB independence \\ S3 - TI theory OR AB theory OR TI concept OR AB concept \\ S1 AND S2 AND S3
}

( ( TITLE-ABS-KEY ( patient* ) ) AND ( TITLE-ABS-KEY ( independence ) OR TITLE-ABS-KEY ( autonomy ) ) AND ( ( TITLE-ABS-KEY ( theory ) OR TITLE-ABS-KEY ( concept ) ) ) ) AND NOT ( PMID ( $\left.1^{*}\right)$ OR PMID ( $\left.2^{*}\right)$ OR PMID $\left(3^{*}\right)$ OR PMID $\left(4^{*}\right)$ OR PMID $\left(5^{*}\right)$ OR PMID $\left(6^{*}\right)$ OR PMID $\left.\left(7^{*}\right) \operatorname{OR} \operatorname{PMID}\left(8^{*}\right) \operatorname{OR} \operatorname{PMID}\left(9^{*}\right)\right)$

Database: MEDLINE (VIA PUBMED)

Results: 461

Search strategy (18 de abril de 2020)

(((Patients[MeSH Terms]) OR (patient*[Title/Abstract])) AND (((Independent Living[MeSH Terms]) OR (Personal Autonomy[MeSH Terms])) OR (independence[Title/Abstract]))) AND ((concept[Title/Abstract]) OR (theory[Title/Abstract])) Filters: in the last 10 years, English, Portuguese, Spanish, MEDLINE 
The relevance of articles for review was analyzed by two independent reviewers, using the title and abstract. The full articles were later retrieved after meeting the inclusion criteria. Two reviewers independently analyzed the articles in full text, intending to analyze whether they met the defined inclusion criteria. When there were differences of opinion between the two reviewers, the intervention of the third reviewer was requested. According to the study's objectives, the researchers developed an instrument with the starting point for data extraction.

The following information was mentioned for each study: a) author, year of publication and country; b) methodological design; c) characteristics of the participants; d) name of the instruments; and e) objective ${ }^{(s)}$ of the study.

As shown in Figure 1, the survey identified 1586 articles with possible relevance for the study. Of these, 67 were extracted because they are in duplicate; of the remaining 1519 articles, 1179 articles were excluded after reading the title and abstract, 314 articles were excluded for not meeting the inclusion criteria after reading in full. After that selection, 26 articles were included.

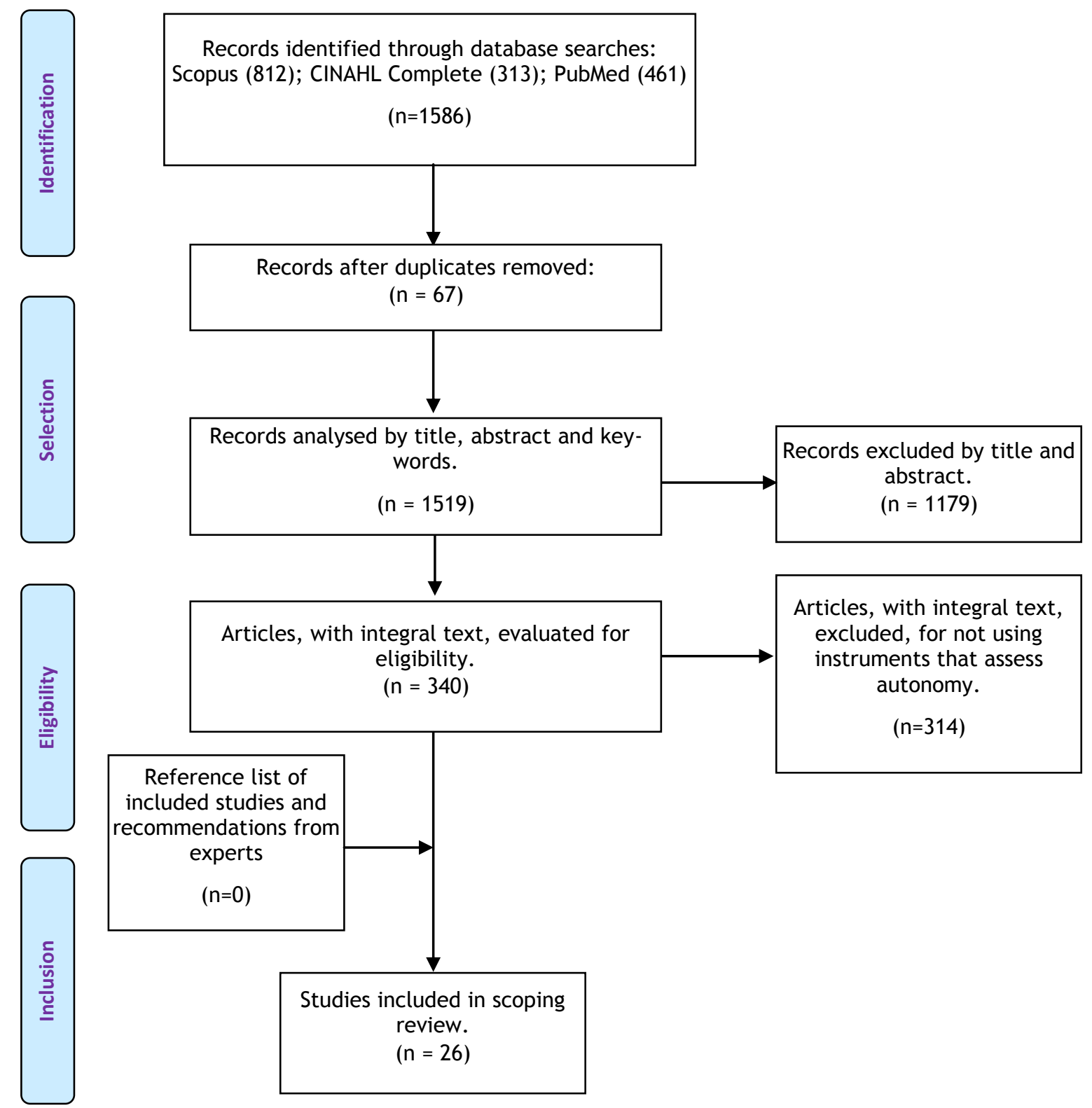

Figure 1 - PRISMA flowchart (adapted) of the study selection process.

Source: Prepared by the authors for the present study

\section{RESULTS}

Of the 26 articles that made up the sample, these are presented in table 2, including the following information: study code, authors and years, type of study, population and country, instruments used to assess independence, and study objectives or hypotheses. 


\begin{tabular}{|c|c|c|c|c|c|}
\hline Study ID & $\begin{array}{l}\text { Type of } \\
\text { Study }\end{array}$ & Title & Population/country & Instruments & Purpose \\
\hline $\begin{array}{l}\text { A1 } \\
\text { (Anggelis et al, } \\
2019 \text { ) }\end{array}$ & $\begin{array}{l}\text { RCT } \\
\text { (Randomized } \\
\text { Control Trial) }\end{array}$ & $\begin{array}{l}\text { Impact of motor } \\
\text { therapy with dynamic } \\
\text { body-weight support } \\
\text { on Functional } \\
\text { Independence } \\
\text { Measures in traumatic } \\
\text { brain injury: An } \\
\text { exploratory study }\end{array}$ & $\begin{array}{l}\text { Patients with Traumatic } \\
\text { Brain Injury who receive } \\
\text { inpatient rehabilitation } \\
\text { incorporating dynamic } \\
\text { body weight support } \\
\text { (DBWS) }(\mathrm{n}=6) \text { and who } \\
\text { received inpatient } \\
\text { rehabilitation without } \\
\text { DBWS }(\mathrm{n}=6) \text { /USA }\end{array}$ & $\begin{array}{l}\text { Functional } \\
\text { Independence } \\
\text { Measurement } \\
\text { (FIM) }\end{array}$ & $\begin{array}{l}\text { To determine whether the use of } \\
\text { dynamic body weight support } \\
\text { allows safe administration of } \\
\text { intensive motor therapy during } \\
\text { hospital rehabilitation and } \\
\text { whether its use improves } \\
\text { functional recovery more than } \\
\text { standard therapy. }\end{array}$ \\
\hline $\begin{array}{l}\text { A2 } \\
\text { (Chang et al., } \\
\text { 2014) }\end{array}$ & $\mathrm{RCT}$ & $\begin{array}{l}\text { Health Service } \\
\text { Management Study for } \\
\text { Stroke: A randomized } \\
\text { Controlled Trial to } \\
\text { Evaluate Two Models } \\
\text { of Stroke Care }\end{array}$ & $\begin{array}{l}41 \text { patients randomized, } \\
20 \text { were allocated co- } \\
\text { located } \\
\text { acute/rehabilitation } \\
\text { stroke care and } 21 \\
\text { traditionally separated } \\
\text { acute/rehabilitation } \\
\text { stroke care/Australia }\end{array}$ & FIM & $\begin{array}{l}\text { Compare the effect of two } \\
\text { models in a randomized } \\
\text { controlled trial on the care of } \\
\text { stroke patients. }\end{array}$ \\
\hline $\begin{array}{l}\text { A3 } \\
\text { (Cheville, } \\
\text { Basford, Dos } \\
\text { Santos, \& } \\
\text { Kroenke, 2014) }\end{array}$ & Quantitative & $\begin{array}{l}\text { Symptom Burden and } \\
\text { Comorbidities Impact } \\
\text { the Consistency of } \\
\text { Responses on Patient- } \\
\text { Reported Functional } \\
\text { Outcomes }\end{array}$ & $\begin{array}{l}163 \text { women with stage IV } \\
\text { breast cancer and } 311 \\
\text { adults with late-stage } \\
\text { lung cancer/USA }\end{array}$ & FIM & $\begin{array}{l}\text { To assess the influence of } \\
\text { symptom intensity, mood and } \\
\text { comorbidities on patient-clinical } \\
\text { agreement and the consistency of } \\
\text { responses to the functional } \\
\text { results reported by the patient }\end{array}$ \\
\hline $\begin{array}{l}\text { A4 } \\
\text { (Gerrard et al., } \\
\text { 2013) }\end{array}$ & $\mathrm{RCT}$ & $\begin{array}{l}\text { Validity and Reliability } \\
\text { of the FIM Instrument } \\
\text { in the Inpatient Burn } \\
\text { Rehabilitation } \\
\text { Population }\end{array}$ & $\begin{array}{l}7569 \text { subjects with burn } \\
\text { injury/USA }\end{array}$ & FIM & $\begin{array}{l}\text { Provide evidence of the validity } \\
\text { of the MIF instrument in the } \\
\text { person with burns in a } \\
\text { rehabilitation program }\end{array}$ \\
\hline $\begin{array}{l}\text { A7 } \\
(\text { Crum, Baltz, \& } \\
\text { Krause, 2019) }\end{array}$ & Case study & $\begin{array}{l}\text { The use of motor } \\
\text { learning and neural } \\
\text { plasticity in } \\
\text { rehabilitation for } \\
\text { ataxic hemiparesis: A } \\
\text { case report }\end{array}$ & $\begin{array}{l}1 \text { inpatient with } \\
\text { stroke/USA }\end{array}$ & FIM & $\begin{array}{l}\text { Describe the intervention } \\
\text { program for a patient with ataxic } \\
\text { hemiparesis, based on principles } \\
\text { of motor learning and neural } \\
\text { plasticity }\end{array}$ \\
\hline $\begin{array}{l}\text { A8 } \\
\text { (Huseyinsinoglu, } \\
\text { Ozdincler, \& } \\
\text { Krespi, 2012) }\end{array}$ & RCT & $\begin{array}{l}\text { Bobath Concept versus } \\
\text { constraint-induced } \\
\text { movement therapy to } \\
\text { improve arm } \\
\text { functional recovery in } \\
\text { stroke patients: a } \\
\text { randomized controlled } \\
\text { trial }\end{array}$ & $\begin{array}{l}24 \text { patients were } \\
\text { randomized to constraint- } \\
\text { induced movement } \\
\text { therapy or Bobath } \\
\text { Concept group/Turkey }\end{array}$ & FIM & $\begin{array}{l}\text { Compare the effects of the } \\
\text { Bobath concept and movement } \\
\text { therapy induced by restrictions } \\
\text { on functional recovery of the } \\
\text { upper limb in stroke patients } \\
\text { with high level of function on the } \\
\text { affected side }\end{array}$ \\
\hline
\end{tabular}




\begin{tabular}{|c|c|c|c|c|c|}
\hline Study ID & $\begin{array}{l}\text { Type of } \\
\text { Study }\end{array}$ & Title & Population/country & Instruments & Purpose \\
\hline $\begin{array}{l}\text { A9 } \\
\text { (Malheiro, } \\
\text { Gaspar, \& } \\
\text { Barros, 2017) }\end{array}$ & Quantitative & $\begin{array}{l}\text { Training Camp: Effects } \\
\text { of an Educational } \\
\text { Program For Self- } \\
\text { management, } \\
\text { Adolescents with Spina } \\
\text { Bifida }\end{array}$ & $\begin{array}{l}56 \text { adolescents with spina } \\
\text { bifida, aged } 10 \text { to } 18 \\
\text { years/USA }\end{array}$ & FIM & $\begin{array}{l}\text { To evaluate a field intervention } \\
\text { with an educational self- } \\
\text { management program among } \\
\text { adolescents with spina bifida }\end{array}$ \\
\hline $\begin{array}{l}\text { A11 } \\
\text { (Pignolo et al., } \\
\text { 2016) }\end{array}$ & $\mathrm{RCT}$ & $\begin{array}{l}\text { A new treatment in } \\
\text { the rehabilitation of } \\
\text { the paretic upper limb } \\
\text { after stroke: the } \\
\text { ARAMIS prototype and } \\
\text { treatment protocol }\end{array}$ & $\begin{array}{l}52 \text { patients enrolled in } \\
\text { the study, } 28 \text { cases } \\
\text { treated with ARAMIS and } \\
24 \text { controls with } \\
\text { conventional } \\
\text { rehabilitation/Italy }\end{array}$ & FIM & $\begin{array}{l}\text { To compare the effectiveness of } \\
\text { robotic rehabilitation by an } \\
\text { exoskeleton prototype system } \\
\text { with traditional rehabilitation in } \\
\text { motor and functional recovery of } \\
\text { the upper limb after stroke }\end{array}$ \\
\hline $\begin{array}{l}\text { A12 } \\
\text { (Prodinger, } \\
\text { O'Connor, } \\
\text { Stucki, \& } \\
\text { Tennant, 2017) }\end{array}$ & Quantitative & \begin{tabular}{|l|} 
Establishing Score \\
Equivalence of the \\
Functional \\
Independence Measure \\
Motor Scale and the \\
Barthel Index, Utilizing \\
the International \\
Classification of \\
Functioning, Disability \\
and Health and Rasch \\
Measurement Theory
\end{tabular} & $\begin{array}{l}2414 \text { from patients } \\
\text { discharged from an } \\
\text { inpatient regional } \\
\text { rehabilitation/United } \\
\text { Kingdom }\end{array}$ & $\begin{array}{l}\text { FIM } \\
\text { Barthel Index }\end{array}$ & $\begin{array}{l}\text { Establish the equivalence } \\
\text { between the total score of the } \\
\text { MIF motor scale and the Barthel } \\
\text { Index by applying the } \\
\text { International Classification of } \\
\text { Functionality, Disability and } \\
\text { Health and theory of Rach } \\
\text { measures }\end{array}$ \\
\hline $\begin{array}{l}\text { A14 } \\
\text { (Saxer et al., } \\
2018)\end{array}$ & RCT & \begin{tabular}{|l|} 
Minimally invasive \\
anterior muscle- \\
sparing versus a \\
transgluteal approach \\
for hemiarthroplasty in \\
femoral neck fractures \\
- a prospective \\
randomized controlled \\
trial including 190 \\
elderly patients
\end{tabular} & $\begin{array}{l}190 \text { elderly } \\
\text { patients/Switzerland }\end{array}$ & FIM & $\begin{array}{l}\text { To evaluate the benefit of an } \\
\text { anterior minimally invasive } \\
\text { approach (AMIS) with a lateral } \\
\text { Harding (LAT) approach for } \\
\text { hemiarthroplasty in patients who } \\
\text { are often fragile }\end{array}$ \\
\hline $\begin{array}{l}\text { A15 } \\
\text { (Todri, Lena, \& } \\
\text { Martínez Gil, } \\
\text { 2019) }\end{array}$ & RCT & $\begin{array}{l}\text { A single blind } \\
\text { randomized controlled } \\
\text { trial of global postural } \\
\text { re-education: } \\
\text { Cognitive effects on } \\
\text { Alzheimer disease } \\
\text { patients }\end{array}$ & $\begin{array}{l}135 \text { patients with } \\
\text { Alzheimer didease/Spain }\end{array}$ & Barthel Index & $\begin{array}{l}\text { It is important to verify that by } \\
\text { modifying and improving postural } \\
\text { attitudes through GPR, a better } \\
\text { concentration of cognitions in } \\
\text { older people is achieved, } \\
\text { increases self-awareness } \\
\text { and proprioception in comparison } \\
\text { with the effects of frequent } \\
\text { therapies implemented in elderly } \\
\text { centers. }\end{array}$ \\
\hline
\end{tabular}




\begin{tabular}{|c|c|c|c|c|c|}
\hline Study ID & $\begin{array}{l}\text { Type of } \\
\text { Study }\end{array}$ & Title & Population/country & Instruments & Purpose \\
\hline $\begin{array}{l}\text { A16 } \\
\text { (Sharma et al., } \\
\text { 2018) }\end{array}$ & $\mathrm{RCT}$ & \begin{tabular}{|l|} 
An open-label proof- \\
of-concept study of \\
intrathecal autologous \\
bone marrow \\
mononuclear cell \\
transplantation in \\
intellectual disability
\end{tabular} & $\begin{array}{l}58 \text { patients with } \\
\text { intellectual } \\
\text { disability/India }\end{array}$ & FIM & $\begin{array}{l}\text { To evaluate the safety, efficacy } \\
\text { and clinical effects of autologous } \\
\text { intrathecal transplantation of } \\
\text { bone marrow mononuclear cells } \\
\text { in a patient with intellectual } \\
\text { disease }\end{array}$ \\
\hline $\begin{array}{l}\text { A17 } \\
\text { (Sharma et al., } \\
\text { 2014) }\end{array}$ & Case study & $\begin{array}{l}\text { Autologous Bone } \\
\text { Marrow Mononuclear } \\
\text { Cells in Ischemic } \\
\text { Cerebrovascular } \\
\text { Accident Paves Way } \\
\text { for Neuro restoration: } \\
\text { A Case Report }\end{array}$ & $\begin{array}{l}1 \text { patient with } \\
\text { Stroke/India }\end{array}$ & FIM & $\begin{array}{l}\text { To observe the effects of } \\
\text { autologous mononuclear cells in } \\
\text { the intrathecal bone marrow on } \\
\text { ischemic stroke }\end{array}$ \\
\hline $\begin{array}{l}\text { A19 } \\
\text { (Richardson, } \\
\text { Isbister, \& } \\
\text { Nicholson, } \\
\text { 2018) }\end{array}$ & Quantitative & \begin{tabular}{|l|} 
A Novel Treatment \\
Protocol (Nocebo \\
Hypothesis Cognitive \\
Behavioural Therapy; \\
NH-CBT) for Functional \\
Neurological Symptom \\
Disorder/Conversion \\
Disorder: A \\
Retrospective \\
Consecutive Case \\
Series
\end{tabular} & $\begin{array}{l}13 \text { patients with } \\
\text { functional neurological } \\
\text { symptom disorder/United } \\
\text { Kingdom }\end{array}$ & FIM & $\begin{array}{l}\text { It was hypothesized that FNSD } \\
\text { arises from a belief of being } \\
\text { neurologically damaged (via a } \\
\text { mechanism akin to a nocebo } \\
\text { response), and an } \\
\text { interdisciplinary treatment } \\
\text { protocol was developed } \\
\text { consistent with this hypothesis, } \\
\text { transparently sharing this theory } \\
\text { with participants. }\end{array}$ \\
\hline $\begin{array}{l}\text { A20 } \\
\text { (Kosteniuk et } \\
\text { al., 2016) }\end{array}$ & Quantitative & \begin{tabular}{|l|} 
Trajectories of \\
Depressive \\
Symptomatology in \\
Rural memory Clinic \\
Patients between \\
Baseline Diagnosis and \\
1-Year Follow-Up
\end{tabular} & $\begin{array}{l}144 \text { patients diagnosed } \\
\text { with no cognitive } \\
\text { impairment, mild } \\
\text { cognitive impairment, } \\
\text { dementia due to } \\
\text { Alzheimer's disease, or } \\
\text { non- Alzheimer's disease } \\
\text { dementia/Canada }\end{array}$ & IADL & $\begin{array}{l}\text { To investigate the prevalence } \\
\text { and trajectory of } \\
\text { symptomatology during } 1 \text {-year } \\
\text { follow-up and the severity of } \\
\text { depressive symptoms, by group of } \\
\text { dementia diagnoses and } \\
\text { determine the predictors of } \\
\text { depressive symptoms during } \\
\text { follow-up }\end{array}$ \\
\hline $\begin{array}{l}\text { A21 } \\
\text { (Watabe et al., } \\
2018)\end{array}$ & Mixed study & $\begin{array}{l}\text { Beneficial falls in } \\
\text { stroke patients: } \\
\text { evaluation using a } \\
\text { mixed method design }\end{array}$ & $\begin{array}{l}123 \text { stroke patients/ } \\
\text { Japan }\end{array}$ & FIM & $\begin{array}{l}\text { To define the process by which } \\
\text { the rehabilitation unit clinician } \\
\text { subjectively defines a fall as a } \\
\text { beneficial event and describes } \\
\text { the characteristics of patients } \\
\text { suffering from beneficial falls }\end{array}$ \\
\hline $\begin{array}{l}\text { A22 } \\
\text { (Putcha \& } \\
\text { Tremont, 2016) }\end{array}$ & $\mathrm{RCT}$ & $\begin{array}{l}\text { Predictors of } \\
\text { independence in } \\
\text { instrumental activities } \\
\text { of daily living: } \\
\text { Amnestic versus } \\
\text { nonamnestic } \mathrm{MCl}\end{array}$ & $\begin{array}{l}170 \text { patients with mild } \\
\text { cognitive } \\
\text { impairment/United } \\
\text { Kingdom }\end{array}$ & IADL & $\begin{array}{l}\text { To determine whether neuro- } \\
\text { psychological measures, as well } \\
\text { as the concept related to the } \\
\text { patient's anosognosia, are } \\
\text { associated with independence in } \\
\text { daily life activities in patients } \\
\text { with mild cognitive impairment } \\
\text { and without any cognitive } \\
\text { impairment }\end{array}$ \\
\hline
\end{tabular}




\begin{tabular}{|c|c|c|c|c|c|}
\hline Study ID & $\begin{array}{l}\text { Type of } \\
\text { Study }\end{array}$ & Title & Population/country & Instruments & Purpose \\
\hline $\begin{array}{l}\text { A23 } \\
\text { (Klietz et al., } \\
2018)\end{array}$ & Quantitative & $\begin{array}{l}\text { Impaired Quality of } \\
\text { Life and Need for } \\
\text { Palliative Care in a } \\
\text { German Cohort of } \\
\text { Advanced Parkinson's } \\
\text { Disease Patients }\end{array}$ & $\begin{array}{l}76 \text { geriatrics patients } \\
\text { with advanced idiopathic } \\
\text { Parkinson's } \\
\text { disease/Germany }\end{array}$ & Barthel Index & $\begin{array}{l}\text { To investigate the current status } \\
\text { of the implementation of } \\
\text { palliative care and quality of life } \\
\text { in a local cohort of patients with } \\
\text { advanced Parkinson's disease, in } \\
\text { order to structure and improve } \\
\text { future care }\end{array}$ \\
\hline $\begin{array}{l}\text { A24 } \\
\text { (Yang \& Lee, } \\
2015)\end{array}$ & Quantitative & $\begin{array}{l}\text { Analysis of the medical } \\
\text { demands of elderly } \\
\text { dementia patients } \\
\text { conserving the } \\
\text { caregiver cost of } \\
\text { medical } \\
\text { accompaniment: an } \\
\text { application of the } \\
\text { travel cost method } \\
\text { and altruistic utility } \\
\text { function }\end{array}$ & $\begin{array}{l}201 \text { dependent older } \\
\text { adults with a risk of } \\
\text { developing Alzheimer's } \\
\text { disease/Taiwan }\end{array}$ & Barthel Index & $\begin{array}{l}\text { Establish an outpatient medical } \\
\text { demand model for visits to } \\
\text { elderly people with dementia and } \\
\text { their caregivers }\end{array}$ \\
\hline $\begin{array}{l}\text { A25 } \\
\text { (Tyson, Burton, } \\
\text { \& McGovern, } \\
\text { 2015) }\end{array}$ & Quantitative & $\begin{array}{l}\text { The effect of a } \\
\text { structured model for } \\
\text { stroke rehabilitation } \\
\text { multidisciplinary team } \\
\text { meetings on functional } \\
\text { recovery and } \\
\text { productivity: a Phase } \\
\text { I/II proof of concept } \\
\text { study }\end{array}$ & $\begin{array}{l}36 \text { inpatients stroke } \\
\text { rehabilitation/United } \\
\text { Kingdom }\end{array}$ & Barthel Index & $\begin{array}{l}\text { Evaluate the feasibility, } \\
\text { acceptability and impact of the } \\
\text { model to structure } \\
\text { multidisciplinary team meetings, } \\
\text { their implementation in } \\
\text { compliance with the quality and } \\
\text { results of patients }\end{array}$ \\
\hline $\begin{array}{l}\text { A26 } \\
\text { (Van Der Zee, } \\
\text { Visser-Meily, } \\
\text { Lindeman, } \\
\text { Kappelle, \& } \\
\text { Post, 2013) }\end{array}$ & Quantitative & $\begin{array}{l}\text { Participation in the } \\
\text { Chronic Phase of } \\
\text { Stroke }\end{array}$ & $\begin{array}{l}111 \text { patients with } \\
\text { Stroke/Netherlands }\end{array}$ & $\begin{array}{l}\text { Utrecht Scale } \\
\text { for Evaluation } \\
\text { of } \\
\text { Rehabilitation } \\
\text { (USER) }\end{array}$ & $\begin{array}{l}\text { To describe the participation } \\
\text { (objective and subjective) and } \\
\text { determine how physical and } \\
\text { cognitive independence and } \\
\text { subjective complaints (pain, } \\
\text { fatigue and mood) influence } \\
\text { participation in community-based } \\
\text { stroke survivors in the } \\
\text { Netherlands }\end{array}$ \\
\hline
\end{tabular}

Source: Prepared by the authors for the present study

The articles were categorized according to the methodology used in the study, with ten quantitative studies, twelve experimental studies, two mixed studies, and two case studies. Five of these studies were carried out in the USA, three in Australia, four in the United Kingdom, two in Japan, two in Italy, two in India, one in Canada, one in Poland, one in Turkey, one in Switzerland, one in Spain, one in Taiwan, Netherlands and Germany.

As for the year of publication, in figure 2, we observe the distribution by year of publication, highlighting that the research was restricted to the period between 2010 and 2020 and that in the ten years included in the research, the years 2016 and 2018 stand out with five articles each.

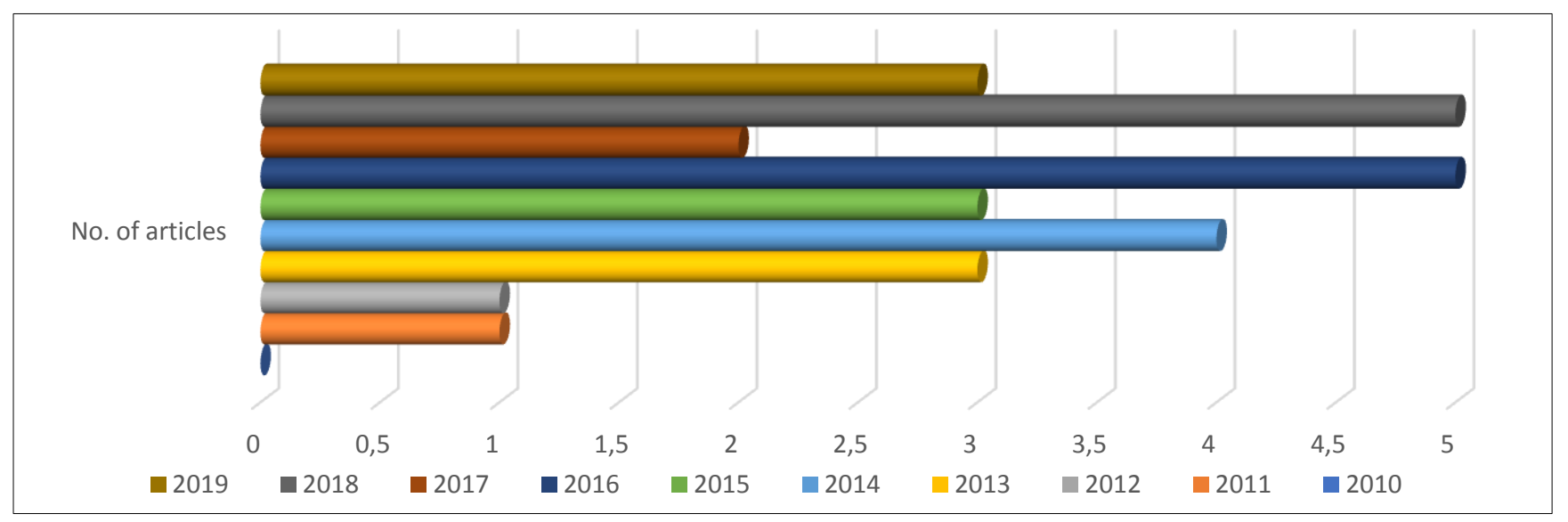

Figure 2 - Distribution of studies, according to the year of publication, 2020.

Source: Prepared by the authors for the present study 
In a total of 26 publications, it was possible to identify six different instruments, namely: Functional Independence Measurement (FIM) $(n=18)$, Instrumental Activities of Daily Living Scale (IADL) or Lawton-Brody Index $(n=3)$, Barthel Index $(n=5)$, Katz Index of Activities of Daily Living (ADLs) $(n=1)$, Assessment of Living Skills and Resources (ALSAR) $(n=1)$ and Utrecht Scale for Evaluation of Rehabilitation (USER) $(n=1)$. Two of the studies selected in the survey used more than one instrument to assess independence.

The FIM is a scale that evaluates the patient's performance in executing a set of 18 tasks. Motor assessment includes the sub-scales: self-care, which is divided into 6 items, toilet control has two items; mobility has 3 items and locomotion, has 2 items. The cognitive assessment of the scale includes the sub-scales: communication with 2 items and social cognition with 3 items. Of the 18 items, 13 assess motor functions and 5 assess cognitive functions. The score for each item varies from 1 to 7 , according to the degree of dependence: 7 corresponds to complete independence, 6 to modified independence, 5 to the need for supervision while performing the task, 4 to minimal help, that is, the patient makes $75 \%$ of the effort required in the task, 3 to moderate help, with the patient performs $50 \%$ of the effort needed to complete the task, 2 maximum help, where the patient performs more than $25 \%$ of the task, 1 full help, that is, the patient has to be replaced for the entire task . In the present study, this instrument stands out, as it was used in 18 of the 26 selected studies .

In the IADL, the person's level of independence is assessed concerning performing instrumental activities that comprise eight tasks such as the ability to use the telephone, shopping, food preparation, housekeeping, laundry, mode of transportation, responsibility for own medications, and ability to handle finances. This instrument is scored from 0 to 8 , where 0 is dependent, and 8 is independent ${ }^{(34)}$. This instrument was used in three of the selected studies .

Barthel Index assesses the patient's level of independence to perform ten activities of daily living such as eating, personal hygiene, using the toilet, bathing, dressing and undressing, sphincter control, walking, transferring from the chair to the bed, up and downstairs. The minimum score is zero and corresponds to the maximum dependency and 100, corresponds to the maximum score, and is equivalent to a state of independence total for the daily activities of life evaluated. Therefore, on this scale the total can vary from zero to 100 , and when the total is between zero and 20, the person has total dependence, between 21 and 60 , it is considered a serious dependency, 61 and 90, a moderate dependency, 91 and 99, a very light dependency and 100, is an independent person ${ }^{(38)}$. This tool was used in five studies of the selected studies ${ }^{(25,39-43)}$.

The ADLs is an appropriate instrument for assessing functional status and serving as a measure of the patient's ability to carry out activities of daily living independently. The scale classifies performance adequacy into six functions: bathing, going to the bathroom, transferring, continence, mobility, dressing/undressing, and feeding. Patients are classified, whether yes or no, for independence in each of the six functions. A score of six indicates the complete function, 4 indicates moderate impairment and 2 or less indicates severe impairment or very dependent ${ }^{(44)}$. Of the selected studies, this tool was only used by one study ${ }^{(30)}$.

ALSAR is a tool that allows to systematically assess the performance of 11 tasks of daily living, classifying the patient's skill levels and resources separately for each task, and combining these levels to determine the risk. These tasks include skills and resources for telephoning, reading, leisure, medication management, money management, transportation, shopping, meal preparation, laundering, housekeeping, and home maintenance. For each task, skills are scored: 0 for independent and consistent performance, 1 for partial performance, and 2 for non-responsibility for the task. For the total of the scale, results between zero and 22 points can be obtained. The resources are scored: 0 for adequate to perform the task consistently, 1 for partially supporting the task, or 2 for insufficient for the task or available resources are not being used. For their application, the authors suggest some questions that facilitated the correct data collection ${ }^{(45)}$. This instrument was used only by one of the selected studies ${ }^{(30)}$.

The USER is a scale that assesses physical and cognitive independence and subjective complaints. This scale allows the evaluation of three dimensions of participation: frequency (objective perspective), restrictions (subjective perspective), and satisfaction (subjective perspective). The physical independence subscale consists of 14 items on mobility and self-care. The Cognitive Independence subscale consists of 10 communication, applied cognition, and behaviour items. All items are scored on a six-point scale, from zero $(<50 \%$ independent) to five (independent without difficulty and assistance or adaptation), with higher scores reflecting more independence. Subjective complaints consist of pain (1 item), fatigue (1 item), and mood (4 items: depressed mood, sadness, anxiety, and anger), all rated on a scale from zero (nothing) to 100 (worse), with higher scores reflecting more subjective complaints ${ }^{(46,47)}$. As for the last two instruments, this one was also used only by one of the selected studies ${ }^{(47)}$.

\section{DISCUSSION}

The use of scales to assess people's needs has increased over time, as has the construction of new tools, as these allow professionals to target the needs of care and at the same time realize the gains in health, with the implementation of specific therapies and intervention programs, thus allowing to reinforce the importance, for health care ${ }^{(48)}$. 
According to the analysis of the concept of independence carried out, an independent person is someone capable of self-care and carrying out daily life activities, both basic life interventions (self-care, mobility, food, personal hygiene, using the toilet, dressing, undressing and putting on shoes), as well as instrumental interventions of daily living (going shopping, managing money, using the phone, cleaning, cooking, use transportation), without the help of third parties ${ }^{(5)}$. Taking into account this analysis, it can be seen that most instruments or assess self-care, also called basic activities of daily living ${ }^{(30,39)}$ or instrumental activities of daily living ${ }^{(30,36)}$, therefore, no instrument evaluates independence in its essence, as they not evaluate the two aspects together.

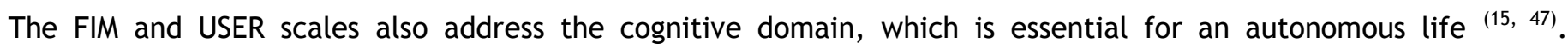
According to the analysis of the concept of autonomy, it comprises the physical domain, the cognitive domain, the social domain, and the management of emotions ${ }^{(6)}$. Considering that these two instruments are used in the area of rehabilitation, the need for them to also understand the cognitive domain is justified, as this can influence health gains in the physical domain and vice versa ${ }^{(49)}$. However, when analyzing the description of the instruments, the authors refer to independence. It can also be inferred that there may be some confusion in the definition of both concepts when it is intended to assess independence and includes aspects that are understood by the concept of autonomy, since in the different areas of knowledge, there is some confusion between autonomy and independence. In clinical practice, in the health area, the term independence is regularly seen when it is intended to promote autonomy and vice versa.

Suppose the professional, namely the nurse, intends to assess autonomy, in the true essence of the concept. In that case, they should use concomitantly other instruments besides those mentioned, because only then will they be able to measure what they want. In addition to the instruments described, some intend to measure autonomy such as: The Health Care Climate Questionnaire, Treatment Self-Regulation Scale, Basic Needs Satisfaction in General Scale, Impact Participation and Autonomy, Autonomy Preference Index and the Perceived Parental Autonomy Support Scale, for example. However, these instruments must be translated and validated for the Portuguese population.

Maintaining activities of daily living simultaneously favours the cognitive state; thus, motor and social stimulation are fundamental to preserve autonomy in daily activities ${ }^{(50)}$. Thus, it is possible to understand the importance of physical and also cognitive rehabilitation, justifying the disciplinary intervention, in nursing, of the specializations of rehabilitation nursing and mental health and psychiatry ${ }^{(46,47)}$. Through the implementation of rehabilitation programs, these professionals have demonstrated their effectiveness in the physical, cognitive, psychological, and even social recovery ${ }^{(49,50)}$.

The person's cognitive decline may be associated with a specific pattern of functional losses in all activities of daily living, first of all, advanced activities of daily living, followed by instrumental activities of daily living and finally basic activities of living daily ${ }^{(50)}$.

USER also allows the assessment of subjective complaints, which are also essential components in the rehabilitation process, both in the acquisition of physical and cognitive skills. The person's cognitive decline may be associated with a specific pattern of functional losses in all activities of daily living, first of all advanced activities of daily living, followed by instrumental activities of daily living and finally basic activities of living daily or also known as self-care ${ }^{(50)}$. Humor is part of the emotional management capacity, which is part of the concept of autonomy and not that of independence. Although the importance of this is understood for the promotion of independence, through the rehabilitation programs, since this promotion necessarily depends on the person's motivation, it does not measure independence, but rather autonomy.

Therefore, it is suggested that the title of the instruments and their description reflect the evaluated components, that is, the basic activities of daily living, and/or instrumental activities of daily living, both considered in the concept of independence. Health professionals, and in particular nurses, due to their proximity to the patient and their family, must be able to provide appropriate responses to their real needs, being necessary for this, the knowledge of the tools at their disposal and the use of the concepts, which are proper to them ${ }^{(8)}$. When the application of the different instruments is combined, together they can respond to the concept of independence, which is why its implementation is recommended.

The assessment instruments implemented in clinical practice thus constitute essential tools that collaborate in identifying real or potential problems of the person being cared for. Hence, their correct application is essential, so that the definition of this same problem is correctly systematized thus contributing, for the prescription of necessary nursing interventions. Only with a thorough knowledge of these components, each professional can reflect and examine their practices and be able to maintain or modify their performance.

Although the time limit of 10 years was chosen to obtain the most recent evidence, this is still a limitation of the present study. Also, it would be interesting to increase the search in more databases, which is another limitation of the present study. A limitation of the studies included in this scoping is the confusion between autonomy and independence concepts, which we tried to clarify. 


\section{CONCLUSION}

The present study sought to map the instruments to assess independence, using a scoping review, noting that the most used instrument is the FIM and then the Barthel index, the IADL, the Katz Index of Activities of Daily Living. ALSAR and USER, in the selected studies, were the least used.

Since there are no measurements/evaluations, as there is no instrument that assesses only, or in isolation, independence, the quality of care provided and its gains in this dimension become difficult to measure.

Scientific evidence recognizes the relationship between the quality of care provided and the application of instruments capable of measuring health gains. The assessment instruments are thus considered essential tools for the practice of care. These allow professionals to know the health status of the people they care for, combined with clinical evaluation, and direct care, according to the person's real or potential needs. Being the nurse, the professional who gathers skills to promote independence, it is up to this professional to know in detail the tools they have available to carry out this assessment. The importance of independence for the quality of life that the person experiences is recognized. In this way, these professionals could contribute to obtaining health gains and, consequently, promoting the health of populations.

\section{REFERENCES}

1. Asghari M, Behzadipour S, Taghizadeh G. A planar neuro-musculoskeletal arm model in post-stroke patients. Biol Cybern. 2018;112(5):483-94. Doi: 10.1007/s00422-018-0773-y

2. Bray L, Kirk S, Callery P. Developing biographies: the experiences of children, young people and their parents of living with a long-term condition. Sociology of Health \& Illness. 2014;36(6):823-39. Doi:10.1111/1467-9566.12110

3. Martinis JG. "the Right to Make Choices": How vocational rehabilitation can help young adults with disabilities increase self-determination and avoid guardianship. Journal of Vocational Rehabilitation. 2015;42(3):221-7. Doi:10.3233/JVR-150742

4. Rodrigues C, Mendonça D, Martins MMPS. Basic self-care in older acute medical in-patients: a retrospective cohort study. Porto Biomedical Journal. 2018;1(3):1-6. Doi: 10.1016/j.pbj.0000000000000001

5. Lima AMN, Martins MMPS, Ferreira MSM, Fernandes CS, Schoeller S, Parola V. Do conceito de independência ao questionamento do seu uso na prática: Uma Scoping (in press). Enfermería Global. 2020.

6. Lima AMN, Martins MMPS, Ferreira MSM, Fernandes CS, Schoeller S, Parola V. O conceito multidimensional de autonomia: uma análise conceptual recorrendo a uma scoping review. Revista de Enfermagem Referência. 2020;5(7): e20113. Doi: https://doi.org/10.12707/RV20113

7. Durocher E, Kinsella EA, Gibson BE, Rappolt S, Ells C. Engaging older adults in discharge planning: case studies illuminating approaches adopted by family members that promote relational autonomy. Disability \& Rehabilitation. 2019;41(25):3005-15. Doi: $10.1080 / 09638288.2018 .1483430$

8. Watson J. Elucidando a disciplina de enfermagem como fundamental para o desenvolvimento da enfermagem profissional. Texto \& Contexto Enfermagem. 2017;26(4). Doi: 10.1590/0104-07072017002017editorial4

9. Lima AMN, Ferreira MSM, Martins MMPS, Fernandes CS. Influência dos cuidados de enfermagem de reabilitação na recuperação da independência funcional do paciente. Journal Health NPEPS. 2019;4:28-43. Doi: 10.30681/252610104062

10. Lopes MA, Gomes SC, Almada-Lobo B. Os Cuidados de Enfermagem Especializados como Resposta à evolução das necessidades em cuidados de saúde. [Internet] 2018 feb. [cited 2021 Mar 15]. Available from: https://www.ordemenfermeiros.pt/media/5908/estudocuidadosespecializadosenfermagem_inesctecabril2018.pdf

11. Silveira PM, Borgatto AF, Silva KS, Oliveira ESA, Barros MV, Nahas MV. Criação de uma escala de satisfação com a vida por meio de Teoria da Resposta ao Item. Jornal Barsileiro de Psiquiatria. 2015;64(4):272-8. Doi: 10.1590/0047-2085000000089

12. Pearson A, Wiechula R, Court A, Lockwood C. The JBI model of evidence-based healthcare. International Journal of Evidence-Based Healthcare. 2005;3(8):207-15. Doi: 10.1590/0047-2085000000089

13. Peters M, Godfrey C, McInerney P, Soares C, Khalil H, Parker D. The Joanna Briggs Institute reviewers' manual 2015: methodology for JBI scoping reviews. [Internet] 2015 [cited 2021 Mar 15]. Available from: https://pdf4pro.com/view/the-joanna-briggs-institute-reviewersmanual-2015-2a232c.html

14. Linacre JM, Heinemann JW, Wright BD, Granger CV, Hamilton BB. The structure and stability of the functional independence measure. [Internet] 1994 feb. [cited 2021 Mar 20]. Available from: https://www.archives-pmr.org/article/0003-9993(94)90384-0/pdf

15. Anggelis E, Powell ES, Westgate PM, Glueck AC, Sawaki L. Impact of motor therapy with dynamic body-weight support on Functional Independence Measures in traumatic brain injury: An exploratory study. NeuroRehabilitation. 2019;45(4):519-24. Doi: 10.3233/NRE-192898

16. Chan DK, Levi C, Cordato D, O'Rourke F, Chen J, Redmond H, et al. Health service management study for stroke: a randomized controlled trial to evaluate two models of stroke care. Int J Stroke. 2014;9(4):400-5. Doi: 10.1111/ijs.12240

17. Cheville AL, Basford JR, Dos Santos K, Kroenke K. Symptom burden and comorbidities impact the consistency of responses on patientreported functional outcomes. Arch Phys Med Rehabil. 2014;95(1):79-86. Doi: 10.1016/j.apmr.2013.08.009

18. Gerrard P, Goldstein R, Divita MA, Ryan CM, Mix J, Niewczyk P, et al. Validity and reliability of the FIM instrument in the inpatient burn rehabilitation population. Archives of Physical Medicine and Rehabilitation. 2013;94(8):1521-6.e4. Doi: 10.1016/j.apmr.2013.02.019

19. Haines TP, McPhail S. Threat appraisal for harm from falls: Insights for development of education-based intervention. Open Longevity Science. 2011;5:9-15. Doi: 0.2174/1876326X01105010009

20. Crum EO, Baltz MJ, Krause DA. The use of motor learning and neural plasticity in rehabilitation for ataxic hemiparesis: A case report. Physiotherapy Theory and Practice. 2019. Doi: 10.1080/09593985.2019.1566941

21. Huseyinsinoglu BE, Ozdincler AR, Krespi Y. Bobath Concept versus constraint-induced movement therapy to improve arm functional recovery in stroke patients: a randomized controlled trial. Clin Rehabil. 2012;26(8):705-15. Doi: 10.1177/0269215511431903

22. Malheiro MIDDC, Gaspar MF, Barros L. Training CAMP: Effects of an educational program for self-management, on adolescents with spina bifida. [Internet] 2017 [cited 2021 Mar 20]. Available from: https://www.abacademies.org/articles/training-camp-effects-of-an-educationalprogram-for-selfmanagement-on-adolescents-with-spina-bifida-6749.html

23. Ogawa T, Omon K, Yuda T, Ishigaki T, Imai R, Ohmatsu S, et al. Short-term effects of goal-setting focusing on the life goal concept on subjective well-being and treatment engagement in subacute inpatients: a quasi-randomized controlled trial. Clinical Rehabilitation. 
2016;30(9):909-20. Doi: 10.1177/0269215515622671

24. Pignolo L, Lucca LF, Basta G, Serra S, Pugliese ME, Sannita WG, et al. A new treatment in the rehabilitation of the paretic upper limb after stroke: the ARAMIS prototype and treatment protocol. Ann Ist Super Sanita. 2016;52(2):301-8. Doi: 10.4415/ann_16_02_25

25. Prodinger B, O'Connor RJ, Stucki G, Tennant A. Establishing score equivalence of the Functional Independence Measure motor scale and the Barthel Index, utilizing the International Classification of Functioning, Disability and Health and Rasch measurement theory. J Rehabil Med. 2017;49(5):416-22. Doi: 10.2340/16501977-2225

26. Rebagliati GA, Sciumè L, lannello P, Mottini A, Antonietti A, Caserta VA, et al. Frailty and resilience in an older population. The role of resilience during rehabilitation after orthopedic surgery in geriatric patients with multiple comorbidities. Funct Neurol. 2016;31(3):171-7. Doi: $10.11138 /$ fneur/2016.31.3.171

27. Saxer F, Studer P, Jakob M, Suhm N, Rosenthal R, Dell-Kuster S, et al. Minimally invasive anterior muscle-sparing versus a transgluteal approach for hemiarthroplasty in femoral neck fractures-a prospective randomized controlled trial including 190 elderly patients. BMC Geriatr. 2018;18(1):222. Doi: 10.1186/s12877-018-0898-9

28. Sharma A, Sane H, Gokulchandran N, Pai S, Kulkarni P, Ganwir V, et al. An open-label proof-of-concept study of intrathecal autologous bone marrow mononuclear cell transplantation in intellectual disability. Stem Cell Res Ther. 2018;9(1):19. Doi: 10.1186/s13287-017-0748-2

29. Sharma A, Sane H, Nagrajan A, Gokulchandran N, Badhe P, Paranjape A, et al. Autologous bone marrow mononuclear cells in ischemic cerebrovascular accident paves way for neurorestoration: A case report. Case Reports in Medicine. 2014. Doi: 10.1155/2014/530239

30. Singh NA, Quine S, Clemson LM, Williams EJ, Williamson DA, Stavrinos TM, et al. Effects of high-intensity progressive resistance training and targeted multidisciplinary treatment of frailty on mortality and nursing home admissions after hip fracture: A randomized controlled trial. Journal of the American Medical Directors Association. 2012;13(1):24-30. Doi: 10.1016/j.jamda.2011.08.005

31. McKechnie D, Pryor J, Fisher MJ. An examination of patient characteristics that contribute to falls in the inpatient traumatic brain injury rehabilitation setting. Disability \& Rehabilitation. 2017;39(18):1864-71. Doi: 10.1080/09638288.2016.1212112

32. Richardson M, Isbister G, Nicholson B. A Novel Treatment Protocol (Nocebo Hypothesis Cognitive Behavioural Therapy; NH-CBT) for Functional Neurological Symptom Disorder/Conversion Disorder: A Retrospective Consecutive Case Series. Behav Cogn Psychother. 2018;46(4):497-503. Doi: 10.1017/s1352465817000832

33. Watabe T, Suzuki H, Konuki Y, Aoki K, Nagashima J, Sako R. Beneficial falls in stroke patients: evaluation using a mixed method design. Topics in Stroke Rehabilitation. 2018;25(2):137-44. Doi: 10.1080/10749357.2017.1394631

34. Graf C. The Lawton Onstrumental Activities of Daily Living (IADL) Scale. [Internet] 2008 Apr. [cited 2021 Mar 27]. Available from: https://nursing.ceconnection.com/ovidfiles/00000446-200804000-00023.pdf

35. Czyżewski P, Szczepkowski M, Domaniecki J, Dąbek A. Physiotherapy based on PNF concept for elderly people after conventional colon surgery. Pol Przegl Chir. 2013;85(9):475-82. Doi: 10.2478/pjs-2013-0074

36. Kosteniuk JG, Morgan DG, O'Connell ME, Kirk A, Crossley M, Stewart NJ, et al. Trajectories of Depressive Symptomatology in Rural Memory Clinic Patients between Baseline Diagnosis and 1-Year Follow-Up. Dementia and Geriatric Cognitive Disorders Extra. 2016;6(2):161-75. Doi: $10.1159 / 000444790$

37. Putcha D, Tremont G. Predictors of independence in instrumental activities of daily living: Amnestic versus nonamnestic $\mathrm{MCl}$. J Clin Exp Neuropsychol. 2016;38(9):991-1004. Doi: 10.1080/13803395.2016.1181716

38. Sequeira C. Cuidar de idosos dependentes. 2. ${ }^{\text {a }}$ ed. Coimbra: LIDEL. 2018. 392 p.

39. Todri J, Lena O, Martínez Gil JL. A single blind randomized controlled trial of global postural re-education: Cognitive effects on Alzheimer disease patients. European Journal of Psychiatry. 2019;33(2):83-90. Doi: 10.1016/j.ejpsy.2019.01.001

40. Olsen CF, Telenius EW, Engedal K, Bergland A. Increased self-efficacy: The experience of high-intensity exercise of nursing home residents with dementia - A qualitative study. BMC Health Services Research. 2015;15(1). Doi: 10.1186/s12913-015-1041-7

41. Klietz M, Tulke A, Müschen LH, Paracka L, Schrader C, Dressler DW, et al. Impaired quality of life and need for palliative care in a German cohort of advanced Parkinson's disease patients. Frontiers in Neurology. 2018;9(MAR).Doi: 10.3389/fneur.2018.00120

42. Yang SL, Lee CY. Analysis of the medical demands of elderly dementia patients considering the caregiver cost of medical accompaniment: an application of the travel cost method and altruistic utility function. Quality and Quantity. 2015;49(1):423-39. Doi: 10.1007/s11135-014-9994$\mathrm{x}$

43. Tyson SF, Burton L, McGovern A. The effect of a structured model for stroke rehabilitation multi-disciplinary team meetings on functional recovery and productivity: a Phase I/II proof of concept study. Clinical Rehabilitation. 2015;29(9):920-5. Doi: 10.1177/0269215514562591

44. Wallace M, Schelkey M. Katz Index of Independence in Activities of Daily Living (ADL). Available from: https: / /www.alz.org/careplanning/downloads/katz-adl.pdf

45. Williams JH, Drinka TJK, Greenberg JR, Farrell-Holtan J, Euhardy R, Schram M. Development and testing of the assessment of living skills and resources (ALSAR) in elderly community-dwelling veterans. Gerontologist. 1991(31):84-91. Doi: 10.1093/geront/31.1.84

46. Post MWM, van der Zee CH, Hennink J, Schafrat CG, Visser-Meily JMA, van Berlekom SB. Validity of the Utrecht Scale for Evaluation of Rehabilitation-Participation. Disabil Rehabili. 2012(34):478-85. Doi: 10.3109/09638288.2011.608148

47. Van Der Zee CH, Visser-Meily JMA, Lindeman E, Kappelle LJ, Post MWM. Participation in the chronic phase of stroke. Topics in Stroke Rehabilitation. 2013;20(1):52-61. Doi: 10.1310/tsr2001-52

48. Almeida C, Silva C, Rosado D, Miranda D, Oliveira D, Mata F, et al. Manual de Boas Práticas Literacia em Saúde - Capacitação dos Profissionais de Saúde. [Internet] 2019 OUt. [cited 2021 Mar 27]. Available from: https://www.dgs.pt/documentos-e-publicacoes/manual-deboas-praticas-literacia-em-saude-capacitacao-dos-profissionais-de-saude-pdf.aspx

49. Lima AMN, Ferreira MSM, Martins MMPS, Fernandes CS, Moreira MTF, Rodrigues TMP. Independência funcional e o estado confusional de pessoas sujeitas a programa de reabilitação. Journal Health NPEPS. 2020;5(2):145-60. Doi: 10.30681/252610104440

50. Imaginário C, Machado P, Magda R, Antunes C, Martins T. Atividades de vida diária como preditores do estado cognitivo em idosos institucionalizados. Revista Portuguesa de Enfermagem de Saúde Mental. 2017(18):37-43. Doi: 10.19131/rpesm.0190

\section{ETHICAL DISCLOSURES}

\section{Author(s) contribution:}

Conceptualization: AML; MMM; MSF;

Methodology: AML; MMM; MSF;

Validation: AML; MMM; MSF;

Formal analysis: AML; MMM; MSF;

Investigation: AML; MMM; MSF; 
Data processing: AML; MMM; MSF; CSF; SDS; VSOP;

Preparation of the original draft: AML; MMM; MSF;

Writing and editing: AML; MMM; MSF; CSF; SDS; VSOP;

Revision: AML; MMM; MSF; CSF; SDS; VSOP;

All authors read and agreed with the published version of the manuscript.

Financing:

This work did not receive any financial contribution or scholarship.

Thanks:

The authors are grateful to Universidade Fernando Pessoa.

Interest conflicts:

The authors do not declare any conflict of interest.

Provenance and peer review:

Not commissioned; externally peer-reviewed.

(C) Autor (es) (ou seu (s) empregador (es)) e APER/RPER 2022. Reutilização permitida de

(c) (i) () $\Theta$ acordo com CC BY-NC-ND. Nenhuma reutilização comercial. 